\title{
Anti-inflammatory and analgesic activities of some newly synthesized pyridinedicarbonitrile and benzopyranopyridine derivatives
}

\author{
HANAA M. HOSNI ${ }^{1 *}$ \\ MOHAMED M. ABDULLA ${ }^{2}$ \\ 1 Pesticide Chemistry Department \\ National Research Centre \\ Doki, Cairo, Egypt \\ 2 Research Units, Hi-Care \\ Pharmaceutical Co. \\ Cairo, Egypt
}

Accepted March 27, 2008

\begin{abstract}
In continuation of our search for new substituted pyridine based anti-inflammatories, reaction of 1-(2-thienyl or furanyl)-3-(2-hydroxyphenyl)-2-propen-1-ones (1) with malononitrile in alcoholic $\mathrm{KOH}$ solution afforded a mixture of 4-alkoxy-2-(2-thienyl or furanyl)-5H-[1]benzopyrano[3,4-c]pyridine-5-ones (2) and 2-alkoxy-4-amino-6(2-thienyl or furanyl)-3,5-pyridinedicarbonitriles (3). Some of the synthesized compounds were evaluated for their anti-inflammatory and analgesic activities compared to diclofenac potassium as positive control. Detailed synthesis, spectroscopic and toxicity data are reported.
\end{abstract}

Keywords: pyridinedicarbonitrile, benzopyranopyridine, anti-inflammatory, analgesic agents

Various 2-propen-1-ones react with malononitrile under basic catalysis to yield cyclohexanol derivatives. This happens via double Michael reaction of malononitrile with propenone, followed by intramolecular cyclization under basic conditions (1-3). On the other hand, reaction of 1,3-diaryl-2-propen-1-ones with malononitrile in the presence of a sufficient amount of alkoxide anion led to the formation of 2-alkoxy-3-cyanopyridines (1-4). Numerous condensed pyridine carbonitrile systems were obtained under similar conditions by the reaction of malononitrile with various $\alpha, \beta$-unsaturated ketones (5-9). In the present work, the reaction of 1-(2-thienyl or furanyl)-3-(2-hydroxyphenyl)-2-propen-1-ones with malononitrile in the presence of a sufficient amount of alkoxide anion was investigated. The hydroxyl group might behave as an active nucleophilic centre, affording condensed $5 \mathrm{H}$-[1]benzopyrano[3,4-c]pyridine derivatives. The synthesis of this condensed heterocyclic system is interesting because of the potential biological activities associated with its structure, such as antipsychotic dopamine $\mathrm{D}_{4}$ receptor antagonist (10), cancer chemopreventive (11), antibacterial (including anti-tubercular) (12), antirheumatic (13), against Alzheimer disease, Parkinson's disease, anxiety, depression, allergic responses and sedation (14). On the other hand, polysubstituted pyridines, especially the 3,5-pyridinedicarbonitriles, are interesting as antioxidants and NADH co-enzyme

*Correspondence, e-mail: hanaanrc@yahoo.com 
H. M. Hosni and M. M. Abdulla: Anti-inflammatory and analgesic activities of some newly synthesized pyridinedicarbonitrile and benzopyrano-pyridine derivatives, Acta Pharm. 58 (2008) 175-186.

analogues that mediate hydrogen transfer in biological systems (15), and for their antihistaminic (16), anti-inflammatory and analgesic activity (17-19).

\section{EXPERIMENTAL}

Melting points were determined on the Electrothermal 9100 melting point apparatus (Electrothermal, UK) and are uncorrected. Microanalytical data (Elementar, Vario EL, USA) were found within $\pm 0.4 \%$ of the theoretical values. The IR spectra ( $\mathrm{KBr}$ ) were recorded on a FT-IR NEXCES spectrophotometer (Shimadzu, Japan). The ${ }^{1} \mathrm{H}$ NMR spectra were measured with a Jeol ECA $500 \mathrm{MHz}$ (Japan) in DMSO- $d_{6}$ or $\mathrm{CDCl}_{3}$ and chemical shifts were recorded in $\delta \mathrm{ppm}$ relative to TMS. Mass spectra (EI) were run at $70 \mathrm{eV}$ with a Finnigan SSQ 7000 spectrometer (Thermo-Instrument System Incorporation, USA). The reactions were followed by TLC (silica gel, aluminum sheets $60 \mathrm{~F}_{254}$, Merck, Germany).

The starting compounds [1-(2-thienyl or furanyl)-3-(2-hydroxyphenyl)-2-propen-1-ones] (1a-c) were prepared according to previously reported procedures (20).

Table I. Physical and analytical data of newly synthesized compounds

\begin{tabular}{|c|c|c|c|c|c|c|c|c|c|}
\hline \multirow{2}{*}{$\begin{array}{l}\text { Compd. } \\
\text { No. }\end{array}$} & \multirow{2}{*}{$x$} & \multirow{2}{*}{$\mathrm{R}$} & \multirow{2}{*}{$\mathrm{R}^{\prime}$} & \multirow{2}{*}{$\begin{array}{l}\text { Yield } \\
(\%)\end{array}$} & \multirow{2}{*}{ M.p. $\left({ }^{\circ} \mathrm{C}\right)$} & \multirow{2}{*}{$\begin{array}{l}\text { Molecular } \\
\text { formula } \\
\left(M_{\mathrm{r}}\right)^{\mathrm{a}}\end{array}$} & \multicolumn{3}{|c|}{$\begin{array}{l}\text { Elemental analysis } \\
\text { Calcd./found }\end{array}$} \\
\hline & & & & & & & $\mathrm{C}$ & $\mathrm{H}$ & $\mathrm{N}$ \\
\hline $2 a$ & S & $\mathrm{H}$ & $\mathrm{CH}_{3}$ & 30 & $226-228$ & $\begin{array}{l}\mathrm{C}_{17} \mathrm{H}_{11} \mathrm{NO}_{3} \mathrm{~S} \\
(309.32)\end{array}$ & $\begin{array}{l}66.02 \\
66.10\end{array}$ & $\begin{array}{l}3.56 \\
3.50\end{array}$ & $\begin{array}{l}4.53 \\
4.45\end{array}$ \\
\hline $2 b$ & S & $\mathrm{H}$ & $\mathrm{C}_{2} \mathrm{H}_{5}$ & 20 & $162-164$ & $\begin{array}{l}\mathrm{C}_{18} \mathrm{H}_{13} \mathrm{NO}_{3} \mathrm{~S} \\
(323.34)\end{array}$ & $\begin{array}{l}66.86 \\
66.66\end{array}$ & $\begin{array}{l}4.02 \\
3.90\end{array}$ & $\begin{array}{l}4.33 \\
4.13\end{array}$ \\
\hline $2 c$ & $S$ & $\mathrm{OCH}_{3}$ & $\mathrm{CH}_{3}$ & 30 & $258-260$ & $\begin{array}{c}\mathrm{C}_{18} \mathrm{H}_{13} \mathrm{NO}_{4} \mathrm{~S} \\
(339.34)\end{array}$ & $\begin{array}{l}63.71 \\
63.55\end{array}$ & $\begin{array}{l}3.83 \\
3.77\end{array}$ & $\begin{array}{l}4.13 \\
4.00\end{array}$ \\
\hline $2 d$ & S & $\mathrm{OCH}_{3}$ & $\mathrm{C}_{2} \mathrm{H}_{5}$ & 30 & $226-228$ & $\begin{array}{l}\mathrm{C}_{19} \mathrm{H}_{15} \mathrm{NO}_{4} \mathrm{~S} \\
(353.37)\end{array}$ & $\begin{array}{l}64.58 \\
64.45\end{array}$ & $\begin{array}{l}4.28 \\
4.20\end{array}$ & $\begin{array}{l}3.96 \\
4.00\end{array}$ \\
\hline $2 e$ & $\mathrm{O}$ & $\mathrm{H}$ & $\mathrm{CH}_{3}$ & 25 & 190-192 & $\begin{array}{l}\mathrm{C}_{17} \mathrm{H}_{11} \mathrm{NO}_{4} \\
\quad(293.26)\end{array}$ & $\begin{array}{l}69.62 \\
69.70\end{array}$ & $\begin{array}{l}3.78 \\
3.70\end{array}$ & $\begin{array}{l}4.77 \\
4.80\end{array}$ \\
\hline $2 \mathrm{f}$ & $\mathrm{O}$ & $\mathrm{H}$ & $\mathrm{C}_{2} \mathrm{H}_{5}$ & 20 & $180-182$ & $\begin{array}{c}\mathrm{C}_{18} \mathrm{H}_{13} \mathrm{NO}_{4} \\
(307.28)\end{array}$ & $\begin{array}{l}70.50 \\
70.40\end{array}$ & $\begin{array}{l}4.26 \\
4.20\end{array}$ & $\begin{array}{l}4.56 \\
4.50\end{array}$ \\
\hline $3 a$ & S & - & $\mathrm{CH}_{3}$ & 25 & $261-263$ & $\begin{array}{l}\mathrm{C}_{12} \mathrm{H}_{8} \mathrm{~N}_{4} \mathrm{OS} \\
(256.27)\end{array}$ & $\begin{array}{l}56.24 \\
56.15\end{array}$ & $\begin{array}{l}3.15 \\
3.10\end{array}$ & $\begin{array}{l}21.86 \\
21.71\end{array}$ \\
\hline $3 b$ & S & - & $\mathrm{C}_{2} \mathrm{H}_{5}$ & 20 & $250-252$ & $\begin{array}{l}\mathrm{C}_{13} \mathrm{H}_{10} \mathrm{~N}_{4} \mathrm{OS} \\
(270.30)\end{array}$ & $\begin{array}{l}57.76 \\
57.80\end{array}$ & $\begin{array}{l}3.73 \\
3.66\end{array}$ & $\begin{array}{l}20.73 \\
20.65\end{array}$ \\
\hline $3 e$ & $\mathrm{O}$ & - & $\mathrm{CH}_{3}$ & 20 & $272-274$ & $\begin{array}{l}\mathrm{C}_{12} \mathrm{H}_{8} \mathrm{~N}_{4} \mathrm{O}_{2} \\
(240.21)\end{array}$ & $\begin{array}{l}59.99 \\
60.05\end{array}$ & $\begin{array}{l}3.36 \\
3.30\end{array}$ & $\begin{array}{l}23.33 \\
23.30\end{array}$ \\
\hline $3 f$ & $\mathrm{O}$ & - & $\mathrm{C}_{2} \mathrm{H}_{5}$ & 20 & 253-255 & $\begin{array}{l}\mathrm{C}_{13} \mathrm{H}_{10} \mathrm{~N}_{4} \mathrm{O}_{2} \\
(254.24)\end{array}$ & $\begin{array}{l}61.41 \\
61.30\end{array}$ & $\begin{array}{l}3.96 \\
3.90\end{array}$ & $\begin{array}{l}22.03 \\
22.00\end{array}$ \\
\hline
\end{tabular}


H. M. Hosni and M. M. Abdulla: Anti-inflammatory and analgesic activities of some newly synthesized pyridinedicarbonitrile and benzopyrano-pyridine derivatives, Acta Pharm. 58 (2008) 175-186.

Table II. Spectral data of newly synthesized compounds

\begin{tabular}{|c|c|c|c|c|}
\hline $\begin{array}{l}\text { Compd. } \\
\text { No. }\end{array}$ & $\begin{array}{c}\text { Mass } \\
(m / z, \%)\end{array}$ & $\begin{array}{c}\mathrm{IR} \\
\left(v, \mathrm{~cm}^{-1}\right)\end{array}$ & $\begin{array}{l}{ }^{1} \mathrm{H} \text { NMR } \\
(\delta, \mathrm{ppm})\end{array}$ & $\begin{array}{l}{ }^{13} \mathrm{C} \text { NMR } \\
(\delta, \mathrm{ppm})\end{array}$ \\
\hline $2 a$ & $\begin{array}{l}309\left[\mathrm{M}^{+}\right](100), \\
310\left[\mathrm{M}^{+}+1\right] \\
(30), 311 \\
{\left[\mathrm{M}^{+}+2\right](10)} \\
282(8), 281 \\
(16), 278(6)\end{array}$ & $\begin{array}{l}1732(\mathrm{C}=\mathrm{O}), 1578 \\
1540(\mathrm{C}=\mathrm{N}, \mathrm{C}=\mathrm{C})\end{array}$ & $\begin{array}{l}4.00\left(\mathrm{~s}, 3 \mathrm{H}, \mathrm{OCH}_{3}\right), \\
8.60-7.20(\mathrm{~m}, 8 \mathrm{H}, 4 \mathrm{Ph}, \\
3 \text { thio, } 1 \mathrm{H})^{\mathrm{a}}\end{array}$ & \\
\hline $2 b$ & $\begin{array}{l}323\left[\mathrm{M}^{+}\right](80), \\
324\left[\mathrm{M}^{+}+1\right] \\
(16), 325 \\
{\left[\mathrm{M}^{+}+2\right](8), 310} \\
(6), 296(8), 280 \\
(37)\end{array}$ & $\begin{array}{l}1738(\mathrm{C}=\mathrm{O}), 1594, \\
1544(\mathrm{C}=\mathrm{N}, \mathrm{C}=\mathrm{C})\end{array}$ & $\begin{array}{l}1.70-1.40(\mathrm{~m}, 3 \mathrm{H}, \\
\left.\mathrm{CH}_{2} \mathrm{CH}_{3}\right), 4.73(\mathrm{q}, 2 \mathrm{H}, \\
\left.\mathrm{CH}_{3} \mathrm{CH}_{2}, J=6.9 \mathrm{~Hz}\right), \\
8.50-7.05(\mathrm{~m}, 8 \mathrm{H}, 4 \mathrm{Ph}, \\
3 \text { thio, } 1 \mathrm{H})^{\mathrm{a}}\end{array}$ & $\begin{array}{l}14.84\left(\mathrm{CH}_{3}\right), 63.28 \\
\left(\mathrm{OCH}_{2}\right), 101.64, \\
104.07,116.66, \\
117.44,124.82,125.78 \\
(\mathrm{Ph} .), 128.97,129.46, \\
131.56,133.41 \\
\text { (thiophene), 143.76, } \\
\text { 147.10, 153.05, } \\
154.46,155.99(\mathrm{pyr}), \\
163.77(\mathrm{C}=\mathrm{O})^{\mathrm{a}}\end{array}$ \\
\hline $2 c$ & - & $\begin{array}{l}1730(\mathrm{C}=\mathrm{O}), 1583, \\
1477(\mathrm{C}=\mathrm{N}, \mathrm{C}=\mathrm{C})\end{array}$ & $\begin{array}{l}3.90\left(\mathrm{~s}, 3 \mathrm{H}, \mathrm{OCH}_{3}\right), 4.21 \\
\left(\mathrm{~s}, 3 \mathrm{H}, \mathrm{OCH}_{3}\right), 7.09-7.80 \\
(\mathrm{~m}, 7 \mathrm{H}, 3 \mathrm{Ph}, 3 \text { thio, } \\
1 \mathrm{H})^{\mathrm{b}}\end{array}$ & \\
\hline $2 d$ & - & $\begin{array}{l}1636(\mathrm{C}=\mathrm{O}), 1583, \\
1484(\mathrm{C}=\mathrm{N}, \mathrm{C}=\mathrm{C})\end{array}$ & $\begin{array}{l}1.52-1.50(\mathrm{~m}, 3 \mathrm{H}, \\
\left.\mathrm{CH}_{2} \mathrm{CH}_{3}\right), 3.90(\mathrm{~s}, 3 \mathrm{H}, \\
\left.\mathrm{OCH}_{3}\right), 4.62(\mathrm{q}, 2 \mathrm{H}, \\
\left.\mathrm{CH}_{3} \mathrm{CH}_{2}, J=6.8 \mathrm{~Hz}\right), \\
7.68-6.96(\mathrm{~m}, 7 \mathrm{H}, 3 \mathrm{Ph}, \\
3 \text { thio, } 1 \mathrm{H})^{\mathrm{b}}\end{array}$ & \\
\hline $2 e$ & - & $\begin{array}{l}1730(\mathrm{C}=\mathrm{O}), 1600, \\
1573(\mathrm{C}=\mathrm{N}, \mathrm{C}=\mathrm{C})\end{array}$ & $\begin{array}{l}3.71\left(\mathrm{~s}, 3 \mathrm{H}, \mathrm{OCH}_{3}\right) \\
8.44-6.75(\mathrm{~m}, 8 \mathrm{H}, 4 \mathrm{Ph}, \\
3 \text { furo, } 1 \mathrm{H})^{\mathrm{a}}\end{array}$ & \\
\hline $2 f$ & - & $\begin{array}{l}1728(\mathrm{C}=\mathrm{O}), 1610, \\
1573(\mathrm{C}=\mathrm{N}, \mathrm{C}=\mathrm{C})\end{array}$ & $\begin{array}{l}1.43\left(\mathrm{~m}, 3 \mathrm{H}, \mathrm{CH}_{3} \text { ethyl), }\right. \\
4.58\left(\mathrm{q}, 2 \mathrm{H}, \mathrm{CH}_{2} \mathrm{CH}_{3}, J\right. \\
=7.2 \mathrm{~Hz}), 8.46-7.40(\mathrm{~m}, \\
8 \mathrm{H}, 4 \mathrm{Ph}, 3 \text { furo, } 1 \mathrm{H})^{\mathrm{a}}\end{array}$ & \\
\hline $3 a$ & $\begin{array}{l}256\left[\mathrm{M}^{+}\right](100), \\
257\left[\mathrm{M}^{+}+1\right] \\
(18), 258 \\
{\left[\mathrm{M}^{+}+2\right](7),} \\
255(88), 227 \\
(33), 226(26), \\
201(17)\end{array}$ & $\begin{array}{l}3339,3243\left(\mathrm{NH}_{2}\right), \\
2214(\mathrm{C} \equiv \mathrm{N}), 1649, \\
1562(\mathrm{C}=\mathrm{N}, \mathrm{C}=\mathrm{C})\end{array}$ & $\begin{array}{l}3.28\left(\mathrm{~s}, 3 \mathrm{H}, \mathrm{OCH}_{3}\right) \\
8.25-7.20(\mathrm{~m}, 5 \mathrm{H}, 3 \mathrm{H} \\
\left.\text { thio, } \mathrm{NH}_{2}\right)^{\mathrm{a}}\end{array}$ & $\begin{array}{l}55.21\left(\mathrm{OCH}_{3}\right), 76.11, \\
83.58(\text { hetero-C-5,3), } \\
113.90,116.28 \\
(2 \mathrm{C} \equiv \mathrm{N}), 129.44, \\
130.49,133.49, \\
141.56 \text { (thio), 155.38, } \\
160.16(\text { hetero-C6,2), } \\
166.02\left(\mathrm{C}-\mathrm{NH}_{2}\right)^{\mathrm{a}}\end{array}$ \\
\hline
\end{tabular}


H. M. Hosni and M. M. Abdulla: Anti-inflammatory and analgesic activities of some newly synthesized pyridinedicarbonitrile and benzopyrano-pyridine derivatives, Acta Pharm. 58 (2008) 175-186.

Table II. Continuation

\begin{tabular}{|c|c|c|c|c|}
\hline $\begin{array}{l}\text { Compd. } \\
\text { No. }\end{array}$ & $\begin{array}{c}\text { Mass } \\
(\mathrm{m} / \mathrm{z}, \%)\end{array}$ & $\begin{array}{c}\mathrm{IR} \\
\left(v, \mathrm{~cm}^{-1}\right)\end{array}$ & $\begin{array}{l}{ }^{1} \mathrm{H} \text { NMR } \\
(\delta, \mathrm{ppm})\end{array}$ & $\begin{array}{c}{ }^{13} \mathrm{C} \text { NMR } \\
(\delta, \mathrm{ppm})\end{array}$ \\
\hline $3 b$ & $\begin{array}{l}270\left[\mathrm{M}^{+}\right](100), \\
271\left[\mathrm{M}^{+}+1\right] \\
(31), 272 \\
{\left[\mathrm{M}^{+}+2\right](3), 269} \\
(18), 256(16), \\
242(72), 241 \\
(30), 225(17), \\
200(20) .\end{array}$ & $\begin{array}{l}\text { 3343, } 3241\left(\mathrm{NH}_{2}\right), \\
2217(\mathrm{C} \equiv \mathrm{N}), 1657, \\
1561(\mathrm{C}=\mathrm{N}, \mathrm{C}=\mathrm{C})\end{array}$ & $\begin{array}{l}1.40-1.20(\mathrm{~m}, 3 \mathrm{H}, \\
\left.\mathrm{CH}_{2} \mathrm{CH}_{3}\right), 4.47(\mathrm{q}, 2 \mathrm{H}, \\
\left.\mathrm{CH}_{2} \mathrm{CH}_{3}, J=7.2 \mathrm{~Hz}\right) \\
8.30-7.10(\mathrm{~m}, 5 \mathrm{H}, 3 \text { thio, } \\
\left.\mathrm{NH}_{2}\right)^{\mathrm{a}}\end{array}$ & \\
\hline $3 e$ & & $\begin{array}{l}3331,3238\left(\mathrm{NH}_{2}\right), \\
2217(\mathrm{C} \equiv \mathrm{N}), 1652, \\
1557(\mathrm{C}=\mathrm{N}, \mathrm{C}=\mathrm{C})\end{array}$ & $\begin{array}{l}3.26\left(\mathrm{~s}, 3 \mathrm{H}, \mathrm{OCH}_{3}\right) \\
8.03-6.76(\mathrm{~m}, 5 \mathrm{H}, 3 \text { furo, } \\
\left.\mathrm{NH}_{2}\right)^{\mathrm{a}}\end{array}$ & \\
\hline $3 f$ & & $\begin{array}{l}3338,3340\left(\mathrm{NH}_{2}\right), \\
2215(\mathrm{C} \equiv \mathrm{N}), 1655, \\
1560(\mathrm{C}=\mathrm{N}, \mathrm{C}=\mathrm{C})\end{array}$ & $\begin{array}{l}1.40-1.25(\mathrm{~m}, 3 \mathrm{H}, \\
\left.\mathrm{CH}_{3} \mathrm{CH}_{2}\right) ; 4.48(\mathrm{q}, 2 \mathrm{H}, \\
\mathrm{CH}_{2} \mathrm{CH}_{3}, \mathrm{~J}=6.9 \mathrm{~Hz}, \\
\left.\mathrm{CH}_{2}\right), 8.05-6.76(\mathrm{~m}, 5 \mathrm{H}, \\
\left.3 \text { furo, } \mathrm{NH}_{2}\right)^{\mathrm{a}}\end{array}$ & \\
\hline
\end{tabular}

Solvent: a DMSO- $d_{6},{ }^{\mathrm{b}} \mathrm{CDCl}_{3}$

Syntheses of 4-alkoxy-2-(2-thienyl or furanyl)-5H-[1]benzopyrano[3,4-c]pyridine-

-5-ones (2a-f) and 2-alkoxy-4-amino-6-(2-thienyl or furanyl)-3,5-

-pyridinedicarbonitriles $(3 a-f)$

General procedure. - A mixture of propene-1-ones $(\mathbf{1 a - c})(10 \mathrm{mmol})$ and $0.6 \mathrm{~g}$ malononitrile $(10 \mathrm{mmol})$ in $25 \mathrm{~mL}$ of alcoholic potassium hydroxide (absolute methanol or $4 \%$ ethanol) was stirred at room temperature for appropriate time. The separated solid was collected by filtration, washed with water and purified by silica gel preparative chromatography to afford compounds $\mathbf{2 a}-\mathbf{f}$ and $\mathbf{3 a}-\mathbf{f}$, respectively (Scheme 1 ). For compounds 4-methoxy-2-(2-thienyl)-5H-[1]-benzopyrano[3,4-c]pyridin-5-one (2a), 4-ethoxy-2-(2-thienyl)-5H-[1]benzopyrano[3,4-c]pyridin-5-one (2b), 4-methoxy-2-(2-thienyl)-5H[1]-3-methoxybenzopyrano-[3,4-c]pyridin-5-one (2c) and 4-ethoxy-2-(2-thienyl)-5H-[1]-3-methoxybenzopyrano-[3,4-c]pyridin-5-one (2d) the reaction time was $72 \mathrm{~h}$ and eluent for chromatography was chloroform/light petroleum $\left(60-80{ }^{\circ} \mathrm{C}\right)(3: 1, V / V)$. For 4-methoxy-2-(2-furanyl)-5H-[1]benzopyrano[3,4-c]pyridine-5-one (2e) and 4-ethoxy-2-(2-furanyl)-5H-[1]benzopyrano[3,4-c]pyridine-5-one (2f) the reaction time was $96 \mathrm{~h}$ and eluent for chromatography was chloroform/light petroleum $\left(60-80^{\circ} \mathrm{C}\right)(5: 1, V / V)$. The same eluent was used for 4-amino-2-methoxy-6-(2-thienyl)-3,5-pyridinedincarbonitrile (3a), 4-amino-2-ethoxy-6-(2-thienyl)-3,5-pyridinedicarbonitrile (3b), amino-2-methoxy-6-(thienyl)-3,5-pyridinedicarbonitrile (3c) [yield (30\%), identified as 3a by m.p., mixed m.p., TLC and spectral data in comparison with authentic sample], 4-amino-2-ethoxy-6-(2-thienyl)-3,5-pyridinedicarbonitrile (3d) [yield (20\%); identified as $3 \mathbf{b}$ by m.p., mixed m.p., TLC and spectral data in comparison with authentic sample], 4-amino-2-methoxy-6-(2-fra- 
H. M. Hosni and M. M. Abdulla: Anti-inflammatory and analgesic activities of some newly synthesized pyridinedicarbonitrile and benzopyrano-pyridine derivatives, Acta Pharm. 58 (2008) 175-186.

nyl)-3,5-pyridinedicarbonitrile (3e), and 4-amino-2-ethoxy-6-(2-furanyl)-3,5-pyridinedicarbonitrile (3f)

\section{Pharmacology}

Animals. - Animals were obtained from the animal house colony of the National Research Center, Cairo, Egypt. All animals were allowed free access to water and were kept on a constant standard diet.

All procedures involving animals were carried out in accordance with the guide for the care and use of laboratory animals (National Academy of Science of Egypt) and were approved by the Animals Studies Committee at Washington University.

Adult male albino rats, weighing 150-180 g, were fasted for 12 hours and used for determining the anti-inflammatory activity. Adult Swiss Webster mice of both sexes, weighing 20-25 g, were fasted for 12-24 hours and used for determining the analgesic activity and $L D_{50}$.

Evaluation of anti-inflammatory activity. - The inhibitory activity of the studied compounds on carrageenean-induced rat's paw edema was determined according to the method of Winter et al. (21) (Table III).

Groups of adult male albino rats (150-180 g), 8 animals each, were orally dosed with tested compounds at a dose of $2.5-5.0 \mathrm{mg} \mathrm{kg}^{-1}$ one hour before carrageenean challenge. Foot paw edema was induced by subplantar injection of $0.05 \mathrm{~mL}$ of $1 \%$ suspension of carrageenean in saline into the plantar tissue of one hind paw. An equal volume of saline was injected into the other hind paw and served as control. Four hours after drug administration the animals were decapitated, blood was collected and the paws were rapidly excised.

The average weight of edema was estimated for the treated as well as for the control group and the percentage inhibition of edema was evaluated. Diclofenac potassium ( 2.5 and $5 \mathrm{mg} \mathrm{kg}^{-1}$ ) was employed as standard reference against which the test compounds were compared (25).

Estimation of plasma prostaglandin E2 (PGE2). - This is an ELISA (Enzyme-Linked Immunosorbent Assay) for the quantitative analysis of Prostaglandin E2 levels in biological fluid (22). The test kit (Merck, Germany) operates on the basis of competition between the enzyme conjugate and the PGE2 in the sample for a limited number of binding sites on the antibody coated plate.

The sample [heparinized blood samples collected from rats treated with anti-inflammatory drugs $(n=8)$ ], plasma was separated by centrifugation at $12000 \times g$ for $2 \mathrm{~min}$ at $40{ }^{\circ} \mathrm{C}$ and immediately stored frozen $-20{ }^{\circ} \mathrm{C}$ until use] or standard solution, is first added to the microplate. Next, the diluted enzyme conjugate is added and the mixture is shaken and incubated at room temperature for one hour. During the incubation, competition for binding sites is taking place. The plate is then washed removing all the unbound material. The bound enzyme conjugate is detected by the additions of substrate, which generates an optimal color after 30 minutes. Quantitative test results may be obtained by measuring and comparing the absorbance reading for the samples against the standards with a microplate reader at $650 \mathrm{~nm}$. The extent of color development is inversely proportional to the amount of PGE2 in the sample or standard; e.g., the absence of PGE2 in the 
H. M. Hosni and M. M. Abdulla: Anti-inflammatory and analgesic activities of some newly synthesized pyridinedicarbonitrile and benzopyrano-pyridine derivatives, Acta Pharm. 58 (2008) 175-186.

sample will result in a bright blue color, whereas the presence of PGE2 will result in yellow color development.

\section{Evaluation of analgesic activity}

Sixty Swiss Webster mice were divided into 10 groups. One group was kept as control (received $0.1 \mathrm{~mL}$ saline s.c.), the second group received vehicle $(0.1 \mathrm{~mL} 1 \%$ of gum acacia), and the third received diclofenac potassium in a dose of $2.5 \mathrm{mg} \mathrm{kg}^{-1}$ (diclofenac

Table III. Anti-inflammatory activity of the synthesized compounds

\begin{tabular}{|c|c|c|c|}
\hline Compd. No. & $\begin{array}{c}\text { Dose } \\
\left(\mathrm{mg} \mathrm{kg}^{-1}\right)\end{array}$ & $\begin{array}{l}\text { Protection against } \\
\text { edema }(\%)\end{array}$ & $\begin{array}{c}\text { Inhibition of plasma } \\
\mathrm{PGE}_{2}(\%)\end{array}$ \\
\hline Control $^{\mathrm{a}}$ & 0 & 0 & 0 \\
\hline $2 a$ & $\begin{array}{l}2.5 \\
5\end{array}$ & $\begin{array}{l}88.2 \pm 0.1 \\
99.9 \pm 0.1\end{array}$ & $\begin{array}{l}60.2 \pm 0.1 \\
83.8 \pm 0.2\end{array}$ \\
\hline $2 b$ & $\begin{array}{l}2.5 \\
5\end{array}$ & $\begin{array}{l}88.5 \pm 0.1 \\
98.3 \pm 0.1\end{array}$ & $\begin{array}{l}61.2 \pm 0.1 \\
83.9 \pm 0.1\end{array}$ \\
\hline $2 c$ & $\begin{array}{l}2.5 \\
5\end{array}$ & $\begin{array}{l}83.2 \pm 0.1 \\
94.2 \pm 0.1\end{array}$ & $\begin{array}{l}60.0 \pm 0.1 \\
75.7 \pm 0.1\end{array}$ \\
\hline $2 d$ & $\begin{array}{l}2.5 \\
5\end{array}$ & $\begin{array}{l}79.3 \pm 0.1 \\
93.9 \pm 0.1\end{array}$ & $\begin{array}{l}58.9 \pm 0.1 \\
77.0 \pm 0.1\end{array}$ \\
\hline $2 e$ & $\begin{array}{l}2.5 \\
5\end{array}$ & $\begin{array}{l}72.2 \pm 0.1 \\
77.6 \pm 0.1\end{array}$ & $\begin{array}{l}56.2 \pm 0.1 \\
74.2 \pm 0.1\end{array}$ \\
\hline $2 f$ & $\begin{array}{l}2.5 \\
5\end{array}$ & $\begin{array}{l}89.2 \pm 0.1 \\
99.9 \pm 0.1\end{array}$ & $\begin{array}{l}61.8 \pm 0.1 \\
85.2 \pm 0.1\end{array}$ \\
\hline $3 a$ & $\begin{array}{l}2.5 \\
5\end{array}$ & $\begin{array}{l}98.1 \pm 0.2 \\
99.9 \pm 0.1\end{array}$ & $\begin{array}{l}82.5 \pm 0.1 \\
83.5 \pm 0.1\end{array}$ \\
\hline $3 b$ & $\begin{array}{l}2.5 \\
5\end{array}$ & $\begin{array}{l}91.2 \pm 0.2 \\
99.1 \pm 0.1\end{array}$ & $\begin{array}{l}74.5 \pm 0.1 \\
79.2 \pm 0.1\end{array}$ \\
\hline $3 c$ & $\begin{array}{l}2.5 \\
5\end{array}$ & $\begin{array}{l}98.1 \pm 0.1 \\
99.9 \pm 0.1\end{array}$ & $\begin{array}{l}82.5 \pm 0.1 \\
83.5 \pm 0.1\end{array}$ \\
\hline $3 d$ & $\begin{array}{l}2.5 \\
5\end{array}$ & $\begin{array}{l}91.2 \pm 0.2 \\
99.1 \pm 0.1\end{array}$ & $\begin{array}{l}74.5 \pm 0.1 \\
79.2 \pm 0.1\end{array}$ \\
\hline $3 e$ & $\begin{array}{l}2.5 \\
5\end{array}$ & $\begin{array}{l}77.3 \pm 0.2 \\
91.9 \pm 0.2\end{array}$ & $\begin{array}{l}56.9 \pm 0.1 \\
73.0 \pm 0.1\end{array}$ \\
\hline $3 f$ & $\begin{array}{l}2.5 \\
5\end{array}$ & $\begin{array}{l}77.1 \pm 0.2 \\
91.1 \pm 0.2\end{array}$ & $\begin{array}{l}58.2 \pm 0.1 \\
74.2 \pm 0.1\end{array}$ \\
\hline $\begin{array}{l}\text { Diclofenac } \\
\text { potassium }\end{array}$ & $\begin{array}{l}2.5 \\
5\end{array}$ & $\begin{array}{l}71.3 \pm 0.2 \\
76.9 \pm 0.1\end{array}$ & $\begin{array}{l}55.9 \pm 0.1 \\
73.0 \pm 0.1\end{array}$ \\
\hline
\end{tabular}

All results are significant different from control values at $p \leq 0.005$

a $0.1 \mathrm{~mL}$ saline. 
H. M. Hosni and M. M. Abdulla: Anti-inflammatory and analgesic activities of some newly synthesized pyridinedicarbonitrile and benzopyrano-pyridine derivatives, Acta Pharm. 58 (2008) 175-186.

Table IV. Analgesic activity of the synthesized compounds

\begin{tabular}{ccccccc}
\hline \multirow{2}{*}{$\begin{array}{c}\text { Compd. } \\
\text { No. }\end{array}$} & 10 & 20 & 30 & 60 & 90 & 120 \\
\cline { 2 - 7 } & 0 & 0 & 0 & 0 & 0 & 0 \\
\hline Control & $0.45 \pm 0.02$ & $0.56 \pm 0.01$ & $0.67 \pm 0.02$ & $1.00 \pm 0.01$ & $1.20 \pm 0.01$ & $1.80 \pm 0.01$ \\
2a & $0.40 \pm 0.01$ & $0.50 \pm 0.01$ & $0.60 \pm 0.01$ & $0.99 \pm 0.01$ & $1.00 \pm 0.01$ & $1.76 \pm 0.01$ \\
2b & $0.30 \pm 0.01$ & $0.40 \pm 0.01$ & $0.50 \pm 0.01$ & $0.70 \pm 0.01$ & $0.90 \pm 0.01$ & $1.20 \pm 0.01$ \\
2c & $0.30 \pm 0.01$ & $0.40 \pm 0.01$ & $0.49 \pm 0.01$ & $0.66 \pm 0.01$ & $0.79 \pm 0.01$ & $1.00 \pm 0.01$ \\
2d & $0.61 \pm 0.02$ & $0.71 \pm 0.02$ & $0.81 \pm 0.02$ & $0.90 \pm 0.02$ & $1.20 \pm 0.01$ & $2.20 \pm 0.01$ \\
2e & $0.86 \pm 0.01$ & $1.21 \pm 0.01$ & $1.47 \pm 0.01$ & $1.30 \pm 0.01$ & $2.24 \pm 0.01$ & $2.33 \pm 0.02$ \\
2f & $0.45 \pm 0.01$ & $0.55 \pm 0.01$ & $0.66 \pm 0.01$ & $1.00 \pm 0.01$ & $1.12 \pm 0.01$ & $1.79 \pm 0.01$ \\
3a & $1.25 \pm 0.01$ & $2.00 \pm 0.01$ & $2.28 \pm 0.01$ & $2.80 \pm 0.01$ & $3.00 \pm 0.01$ & $3.12 \pm 0.01$ \\
3b & $0.45 \pm 0.01$ & $0.55 \pm 0.02$ & $0.66 \pm 0.01$ & $1.00 \pm 0.01$ & $1.12 \pm 0.01$ & $1.79 \pm 0.01$ \\
3c & $1.25 \pm 0.01$ & $2.00 \pm 0.01$ & $2.28 \pm 0.01$ & $2.80 \pm 0.01$ & $3.00 \pm 0.01$ & $3.12 \pm 0.01$ \\
3d & $0.30 \pm 0.01$ & $0.40 \pm 0.01$ & $0.40 \pm 0.01$ & $0.60 \pm 0.01$ & $0.70 \pm 0.01$ & $1.10 \pm 0.01$ \\
3e & $0.61 \pm 0.02$ & $0.81 \pm 0.01$ & $1.25 \pm 0.01$ & $1.43 \pm 0.01$ & $1.60 \pm 0.01$ & $1.81 \pm 0.01$ \\
3f & & & & & & \\
Diclofenac & $1.05 \pm 0.01$ & $1.06 \pm 0.01$ & $1.04 \pm 0.01$ & $1.01 \pm 0.01$ & $1.02 \pm 0.01$ & $1.03 \pm 0.01$ \\
potassium & & & & & & \\
\hline
\end{tabular}

All results are significantly different from control at $p \leq 0.005$.

suspended in $2 \%$ gum acacia suspension) as a reference drug, while the other groups received the test compounds suspended in $2 \%$ gum acacia, s.c. Mice were dropped gently into a dry glass beaker of $1 \mathrm{~L}$ capacity maintained at $55-55.5^{\circ} \mathrm{C}$. Normal reaction time in seconds for all animals was determined at time intervals of 10, 20, 30, 60, 90, and 120 minutes. This is the interval extending from the moment when the mouse reaches the hot beaker till the animal licks its feet or jumps out of the beaker (dose $5 \mathrm{mg} \mathrm{kg}^{-1}$ ). The relative potencies to diclofenac potassium were determined (Table IV).

Determination of acute toxicity $\left(\mathrm{LD}_{50}\right)$

The $L D_{50}$ was determined on mice by injecting increasing doses of test compounds calculating the dose that kills $50 \%$ of the animals, according to Austen et al. (23) (Table V).

\section{RESULTS AND DISCUSSION}

Reaction of 1-(2-thienyl)-3-(2-hydroxyphenyl)-2-propen-1-one (1a), 1-(2-thienyl)-3-(2-hydroxy-3-methoxyphenyl)-2-propen-1-one (1b) or 1-(2-furanyl)-3-(2-hydroxyphenyl)-2-propen-1-one (1c) with malononitrile in alcoholic (methanolic or ethanolic) potassium hydroxide at room temperature with stirring afforded a mixture of two products, 
H. M. Hosni and M. M. Abdulla: Anti-inflammatory and analgesic activities of some newly synthesized pyridinedicarbonitrile and benzopyrano-pyridine derivatives, Acta Pharm. 58 (2008) 175-186.

Table V. Acute toxicity $\left(\mathrm{LD}_{50}\right)$ of the synthesized compounds

\begin{tabular}{cc}
\hline Compd. No. & $L D_{50}\left(\mathrm{mg} \mathrm{kg}^{-1}\right)^{\mathrm{a}}$ \\
\hline $\mathbf{2 a}$ & $2228.31 \pm 0.13$ \\
$\mathbf{2 b}$ & $1192.10 \pm 0.12$ \\
$\mathbf{2 c}$ & $1273.61 \pm 0.11$ \\
$\mathbf{2 d}$ & $1012.61 \pm 0.11$ \\
$\mathbf{2 e}$ & $2345.00 \pm 0.14$ \\
$\mathbf{2 f}$ & $2368.00 \pm 0.15$ \\
3a & $1211.19 \pm 0.11$ \\
3b & $1966.00 \pm 0.16$ \\
3c & $1211.19 \pm 0.12$ \\
3d & $1966.00 \pm 0.15$ \\
3e & $1252.61 \pm 0.11$ \\
3f & $1524.00 \pm 0.16$ \\
Diclofenac potassium & $1988.00 \pm 0.29$ \\
\hline
\end{tabular}

a Mean $\pm \mathrm{SD}, n=24$

All results are significantly different from control at $p \leq 0.005$.

which were isolated by silica gel preparative chromatography. Their structures were established as 4-alkoxy-2-(2-thienyl or furany1)-5H[1]benzopyrano[3,4-c]pyridin-5-ones (2a-f) and 2-alkoxy-4-amino-6-(2-thienyl or furanyl)-3,5-pyridinedicarbonitries (3a-f) based on spectroscopic and elemental analysis data (Tables I and II).

The IR spectra of $\mathbf{2 a - f}$ did not show any absorption assignable to nitrile vibration. However, a strong band due to carbonyl stretching vibration was observed at $v 1738$ $1730 \mathrm{~cm}^{-1}$. ${ }^{1} \mathrm{H}$ NMR spectra of $2 \mathbf{a}-\mathbf{f}$ showed the presence of an alkoxide residue, confirming the involvement of either methoxide (singlet at $\delta 4.0-4.21 \mathrm{ppm}$ ) or ethoxide (triplet at $\delta 1.7-1.50$, quartet at $\delta 4.73-4.62 \mathrm{ppm})$.

The formation of 2 was assumed to take place via Michael addition of active methylene malononitrile to the $\beta$-carbon of 2-propen-1-ones (1a-c). Then cyclization due to the addition of the alkoxide residue at one of the nitrile groups with subsequent nucleophilic attack of the hydroxyl oxygen at the other nitrile function took place. Hydrolysis of the imino group under these reaction conditions afforded eventually the 4-alkoxy-2-(thienyl or furanyl)-5H-[1]benzopyrano[3,4-c]pyridine-5-ones (2a-f) (Scheme 1).

The IR spectra of 3a-f did not show any absorption corresponding to carbonyl function, which was present in the starting material. On the other hand, bands assignable to the amino stretching vibration appeared at $v 3343,3241 \mathrm{~cm}^{-1}$ beside the nitrile stretching vibration bands at $v 2217-2214 \mathrm{~cm}^{-1}$. ${ }^{1} \mathrm{H}$ NMR spectra of 3a-f exhibited the alkoxide residue (singlet at $\delta 3.28-3.00 \mathrm{ppm}$ ) for the methoxide and (triplet at $\delta 1.70-1.50$, quartet at $\delta$ $4.73-4.62 \mathrm{ppm}$ ) for the ethoxide protons, in addition to the amino singlet signal at $\delta$ 7.90-7.60 ppm. 
H. M. Hosni and M. M. Abdulla: Anti-inflammatory and analgesic activities of some newly synthesized pyridinedicarbonitrile and benzopyrano-pyridine derivatives, Acta Pharm. 58 (2008) 175-186.

Formation of 3a-f presumably took place through cleavage of the starting propenones 1a-c, giving rise to the (un)substituted benzoate ester, which in turn interacted with the active methylene malononitrile dimer (formed under the basic reaction conditions). Subsequently, cyclization took place due to alkoxide nucleophilic attack at one of the nitrile groups, finally giving the 4-amino-2-alkoxy-6-(2-thieny or furanyl)-3,5-pyridinedicarbonitriles 3a-f.

All the tested compounds showed potent anti-inflammatory activity and $\mathrm{PEG}_{2}$ inhibition at two dose levels (2.5 and $\left.5 \mathrm{mg} \mathrm{kg}^{-1}\right)$. Compounds $3 \mathbf{a}, 3 \mathbf{c}(\mathbf{3} \mathbf{b}, \mathbf{3 d})$ showed high protection against induced edema, more than $90 \%$, with high percentage inhibition of $\mathrm{PEG}_{2}$, higher than $74 \%$, whereas compounds $\mathbf{2 f}, \mathbf{2 a}, \mathbf{2 b}, \mathbf{2 c}$, $2 \mathbf{2 d}$ showed moderate potency. The degree of potency in descending order is: $3 a, 3 c(3 b, 3 d), 2 f, 2 a, 2 b, 2 c, 2 d, 3 e, 3 f, 2 f$ and $2 \mathbf{e}$.
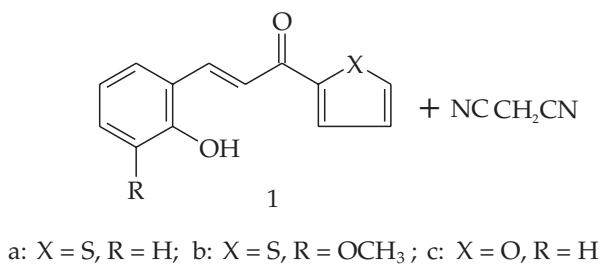

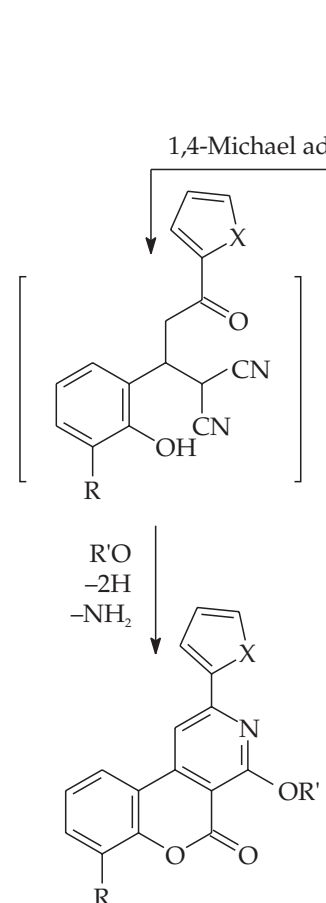

2

$\mathrm{KOH} / \mathrm{R}^{\prime} \mathrm{OH}$

cleavage and addition<smiles>[Y]CC#N</smiles>

R'O<smiles>N#Cc1c(O)nc(-c2ccco2)c(C#N)c1N</smiles><smiles>[R20]c1nc(N)c(C#N)c(-c2ccc[Y]2[H])c1C#N</smiles>

4

Scheme 1 
H. M. Hosni and M. M. Abdulla: Anti-inflammatory and analgesic activities of some newly synthesized pyridinedicarbonitrile and benzopyrano-pyridine derivatives, Acta Pharm. 58 (2008) 175-186.

All tested compounds exhibited analgesic activities (Table IV) that lasted for 120 minutes and the potency increased with time. The most potent compounds were (3d, $3 \mathbf{d})$, nearly 3 times more potent than diclofenac, while compound $\mathbf{2} f$ was 2 times more potent than diclofenac. The degree of potency in descending order is $(\mathbf{3 a}, \mathbf{3 b}), \mathbf{2} \mathbf{f}, \mathbf{2 e}, \mathbf{3} \mathbf{f}, \mathbf{2} \mathbf{a}(\mathbf{3} \mathbf{c}$, $3 a), 2 b, 2 c, 3 e$ and $2 \mathbf{d}$. On the basis of mass-calculated dosage all the tested compounds were more potent than diclofenac potassium (Table III).

The newly synthesized compounds have a high safety margin due to their high $L D_{50}$ (Table V). Compounds $\mathbf{2 f}, \mathbf{2} \mathbf{e}, \mathbf{3} \mathbf{a}$ are safer than diclofenac whereas compounds (3d, $3 b), 3 f, 2 c, 3 e, 3 a, 3 c$ and $\mathbf{2 d}$ are less safe than diclofenac and they are arranged in descending order of safety.

Five membered ring system with one heteroatom is essential for both anti-inflammatory and analgesic activity, whereas polycyclic ring systems play an important role in increasing these activities. Thiophene sharply increases both anti-inflammatory and analgesic activity.

\section{CONCLUSION}

Newly synthesized thienylpyridine carbonitriles and furanyl benzopyranopyridines have proven that both pyridine nucleus and five-membered ring with one heteroatom seem to be essential for anti-inflammatory and analgetic activities. A number of substituents is aimed at studying for their contribution to pharmacological activity.

\section{REFERENCES}

1. J. L. Soto, C. Seoane and J. A. Ciller, Synthesis of heterocycles. XVIII. Preparation of 2,4-diaryl-5-cyano-6-ethoxypyridines, An. Quim. Ser. C 76 (1980) 251-258.

2. N. Mishriky, F. M. Aassad, Y. A. Ibrahim and A. S. Girgis, New pyridinecarbonitriles from fluoroarylpropenones, Recl. Trav. Chim. Pays-Bas 113 (1994) 35-39.

3. M. M. Al-Arab, H. D. Tabba, B. S. Ghanem and M. M. Olmstead, Michael-addition of malononitrile to 1,3-diaryl-2-propen-1-ones, Synthesis 12 (1990) 1157-1159; DOI: 10.1055/s-1990-27123.

4. M. M. Al-Arab, A facile synthesis of 6-alkoxy-2,4-diaryl-5-cyanopyridine, J. Heterocyclic Chem. 26 (1989) 1665-1673.

5. D. V. Tymdall, T. Al-Nakib and M. J. Meegan, A novel synthetic route to phenyl-substituted pyridines synthesis of [1]benzopyrano[3,4-b]pyridines, [1]benzothiopyrano[4,3-b]pyridines and pyrido[3,2-b]benzothiazines(1-azaphenothiazines), Tetrahedron Lett. 29 (1988) 2703-2706; DOI: 10.1016/0040-4039(91)85063-B.

6. Yu. A. Sharanin, V. K. Promonenkov and A. M. Shestopalov, Nitrile cyclization reactions. V. 2-Aryl-3-(2-thienoyl)-1,1-dicyanopropanes and derivatives of pyridines made from them, $\mathrm{Zh}$. Org. Khim. 16 (1980) 2188-2192.

7. N. Mishriky, Y. A. Ibrahim and A. S. Girgis, Synthetic approaches towards 5H-indeno[1,2-b]pyridines, J. Chem. Res. 1997, 316-317; DOI: 10.1039/a608311k.

8. N. Mishriky, Y. A. Ibrahim, A. S. Girgis and N. G. Fawzy, Synthetic approaches towards benzo[h]quinoline-3-carbonitrile, Pharmazie 55 (2000) 269-272. 
9. A. S. Girgis and I. S. Ahmed-Farag, Synthesis of novel 2-alkoxy-5H-benzo[6,7]cyclo-hepta[1, 2-b]pyridine-3-carbonitriles, Z. Naturforsch. 58B (2003) 698-703; DOI: 0932-0776/03/0700-0698.

10. P. C. Unangst, T. Capiris, D. T. Connor, T. G. Heffiner, R. G. Mackenzie, S. R. Miller, T. A. Pugsley and L. D. Wise, Chromeno[3,4-c]pyridine-5-ones: Selective human dopamine D4 receptor antagonists as potential antipsychotic agents, J. Med. Chem. 40 (1997) 2688-2693; DOI: 10.1021/ im970397q.

11. P. Koeckritz, C. Ruhmann, D. Fieblinger, C. D. Schroeder, B. Joksch, H. Heider, B. Weiher and J. Liebscher, Preparation of 2-aminopyridine-3-carbonitriles as human cyclomegalovirus inhibitors, Ger. Offen DE 4, 117, 802, 3 Dec 1992; ref. Chem. Abstr. 118 (1993) 191550s.

12. S. K. Srivastava, R. P. Tripathi and R. J. Ramachandram, NAD ${ }^{+}$-dependent DNA ligase (Rv 3014 c) from Mycobacterium tuberculosis - crystal structure of the adenylation domain and identification of novel inhibitors, J. Biol. Chem. 80 (2005) 30272-30281; DOI: 10.1074/jbc.M503780200.

13. R. M. Weier, L. F. Lee, R. A. Partis and F. J. Koszyk, Preparation of 2,3-substituted pyridines for the treatment of inflammation, U.S. Pat. 96, 24, 584, 15 Aug 1996; ref. Cem. Abstr. 125 (1996) 247624h.

14. B. E. Maurizio, H. T. Gerda, K. G. John and N. R. David, Preparation of pyrimidinamines and pyridinamines as adenosine receptor modulators for treatment of CNS disorders, Int. App. WO 0162, 233, 30 Aug 2001; ref. Chem. Abstr. 135 (2001) 2110495s.

15. U. Eisner and J. Kuthan, The chemistry of dihydropyridines, Chem. Rev. 72 (1972) 1-42; DOI: $10.1021 / \mathrm{cr} 60275 \mathrm{a} 001$.

16. J. M. Ouintela, C. Peinador, L. Botana, M. Estevez and R. Reiguera, Synthesis and antihistaminic activity of 2-guanadino-3-cyanopyridines and pyrido[2,3-d]pyrimidines, Bioorg. Med. Chem. 5 (1997) 1543-1553; DOI: 10.1016/S0968-0896(97)00108-9.

17. F. Monna, F. Chimenti, A. Balasco, B. Bizzarri, W. Filippelli, A. Filippelli and L. Gagliardi, Antiinflammatory, analgesic and antipyretic of 4,6-disubstituted 3-cyano-2-aminopyridines, Eur. J. Med. Chem. 34 (1999) 245-254; DOI: 10.1016/S0223-5234(99)80057-9.

18. K. Ueno, A. Sasaki, K. Kawano, T. Okabe, N. Kitazawa, K. Takahashi, N. Yamamoto and Y. Suzuki, Preparation of Piperazinylisoquinolines and Analogs as Serotonin Antagonists, 15 Apr 1999 Int. Appl. WO 99180 77; ref. Chem. Abstr. 130 (1999) 311813b.

19. R. C. Elderfied and T. P. King, Benzopyrylium salt by hydrocarbon elimination from chromens, J. Am. Chem. Soc. 76 (1954) 5439-5442; DOI: wiley.com/10.1002/9780470145173.ch263.

20. C. A. Winter, E. A. Risely and G. W. Nuss, Anti-infalmmatory and antipyretic activities of indomethacin, 1-(p-chlorobenzyl)-5-methoxy-2-methyl-indole-3-acetic acid, J. Pharmacol. Exp. Ther. 141 (1963) 369-376.

21. K. U. Weithmann, S. Jeske and V. Schlotte, Effect of leflunomide on constitutive and inducible pathways of cellular eicosanoid generation, Agent Actions 41 (1994) 164-170; DOI: 10.1007/ BF02001911.

22. A. Tjlsen, J. H. Rosland, O. G. Berge and K. Hole, The increasing temperature hot plate test: An improved test of nociception in mice and rats, J. Pharmacol. Meth. 25 (1991) 241-250; DOI: 10.1016/0160-5402(91)90014-V.

23. K. F. Austen and W. E. Brocklehurst, Anaphylaxis in chopped guinea pig lung. I. Effect of peptidase substrates and inhibitors, J. Exp. Med. 113 (1961) 521-524. 
H. M. Hosni and M. M. Abdulla: Anti-inflammatory and analgesic activities of some newly synthesized pyridinedicarbonitrile and benzopyrano-pyridine derivatives, Acta Pharm. 58 (2008) 175-186.

\section{$S A \check{Z} E T A K$}

\section{Protuupalno $\mathrm{i}$ analgetsko djelovanje novih derivata piridindikarbonitrila i benzopiranopiridina}

HANAA M. HOSNI i MOHAMED M. ABDULLA

$\mathrm{U}$ nastavku istraživanja derivata piridina $\mathrm{s}$ potencijalnim protuupalnim djelovanjem sintetizirani su 4-alkoksi-2-(2-tienil ili furanil)-5H-[1]benzopirano[3,4-c]piridin-5oni (2) i 2-alkoksi-4-amino-6-(2-tienil ili furanil)-3,5-piridindikarbonitrili (3). Smjesa spojeva 2 i 3 dobivena je reakcijom 1-(2-tienil ili furanil)-3-(2-hidroksifenil)-2-propen-1-ona (1) s malononitrilom $\mathrm{u}$ alkoholnoj otopini $\mathrm{KOH}$. Neki od sintetiziranih spojeva testirani su na protuupalno i analgetsko djelovanje, uz diklofenak kalij kao pozitivnu kontrolu. U radu su dani detaljni sintetski, spektroskopski i toksikološki podaci.

Ključne riječi: piridindikarbonitril, benzopiranopiridin, spojevi s protuupalnim i analgetskim djelovanjem 